Atmos. Chem. Phys., 10, 4283-4293, 2010

www.atmos-chem-phys.net/10/4283/2010/

doi:10.5194/acp-10-4283-2010

(C) Author(s) 2010. CC Attribution 3.0 License.

\title{
A case study of dust aerosol radiative properties over Lanzhou, China
}

\author{
L. Zhang, X. Cao, J. Bao, B. Zhou, J. Huang, J. Shi, and J. Bi \\ Key Laboratory for Semi-Arid Climate Change of the Ministry of Education, College of Atmospheric Sciences, Lanzhou \\ University, Lanzhou, 730000, China
}

Received: 18 November 2009 - Published in Atmos. Chem. Phys. Discuss.: 5 February 2010

Revised: 19 April 2010 - Accepted: 4 May 2010 - Published: 7 May 2010

\begin{abstract}
The vertical distribution of dust aerosol and its radiative properties are analysed using the data measured by the micropulse lidar, profiling microwave radiometer, sunphotometer, particulate monitor, and nephelometer at the Semi-Arid Climate and Environment Observatory of Lanzhou University (SACOL) during a dust storm from 27 March to 29 March 2007. The analysis shows that the dust aerosol mainly exists below $2 \mathrm{~km}$ in height, and the dust aerosol extinction coefficient decreases with height. The temporal evolution of aerosol optical depth (AOD) during the dust storm is characterized by a sub-maximum at 22:00 (Beijing Time), 27 March and a maximum at 12:00, 28 March. The AOD respectively derived by lidar and sunphotometer shows a good consistency. The $\mathrm{PM}_{10}$ concentration and aerosol scattering coefficient share similar variation trends, and their maximums both appear at 22:00, 27 March.

The aerosol extinction coefficient and relative humidity have the similar trends and their maximums almost appear at the same heights, which presents a correlation between extinction coefficient and relative humidity known as aerosol hygroscopicity. The relative humidity is related with temperature, and then the temperature will affect the aerosol extinction properties by modifying the relative humidity condition.

The aerosol extinction coefficient, scattering coefficient, and $\mathrm{PM}_{10}$ concentration present good linear correlations. The correlation coefficients of the aerosol scattering coefficients of 450, 520, and $700 \mathrm{~nm}$ and $\mathrm{PM}_{10}$ concentration, of aerosol extinction coefficient retrieved by lidar at $532 \mathrm{~nm}$ and $\mathrm{PM}_{10}$ concentration, and of aerosol extinction and scattering coefficient are respectively $0.98,0.94$, and 0.96 .
\end{abstract}

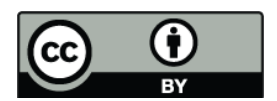

Correspondence to: L. Zhang

(zhanglei@lzu.edu.cn)

\section{Introduction}

Natural and anthropogenic aerosol plays a crucial role in the global and regional climate (Pappalardo et al., 2003). Aerosol affects the Earth and atmospheric radiation budget by directly scattering and absorbing the incoming solar radiation (McCormick and Ludwig, 1967; Charlson and Pilat, 1969; Atwater, 1970; Coakley Jr. et al., 1983) and by indirectly increasing the cloud albedo and suppressing precipitation by modifying cloud microphysical properties as cloud condensation nuclei (Twomey, 1977; Albrecht, 1989). The direct aerosol effect will influence the atmospheric temperature structure and cloud formation (Grassl, 1975; Hansen et al., 1997; Ackerman et al., 2000; Koren et al., 2004).

Dust storms occur frequently in spring and winter in the severe desertification regions. Dust aerosol is a chief contributor to the global aerosol loading (Pierangelo et al., 2004). The dust aerosol severely affects the local climate and environment by influencing the atmospheric radiation balance and decreasing atmospheric visibility (Wang et al., 2005). Recent years have witnessed numerous studies on the aerosol radiative properties (Blanco et al., 2003; Gobbi et al., 2003; Immler et al., 2003; Collaud Coen et al., 2004; Papayannis et al., 2005; Balkanski et al., 2007; Zhang et al., 2007; Su et al., 2008; Hong et al., 2008).

Some aerosol field experiments have also been carried out over the arid region of China, and much research progress has been made (e.g. Iwasaka et al., 2003; Yamada et al., 2005; Shen et al., 2006; Huang et al., 2009; Liu et al., 2002a). However few observations were carried out over the semiarid region of the Loess Plateau. In order to improve the understanding of the impact of human activity on semiarid climate, the Semi-Arid Climate and

Published by Copernicus Publications on behalf of the European Geosciences Union. 
Environment Observatory of Lanzhou University (SACOL, $35^{\circ} 57^{\prime} \mathrm{N}, 104^{\circ} 08^{\prime} \mathrm{E}, 1965.8 \mathrm{~m}$, Fig. 1) was set up in 2005 (Huang et al., 2008a). The location is selected in a rural area far from the populated urban area with comparatively few man-made pollution sources. SACOL measures wind-blown dust and air pollution aerosol radiative properties, especially the dust aerosol effect.

The paper aims to analyse the dust aerosol radiative properties using the data collected by the micropulse lidar, profiling microwave radiometer, sunphotometer, particulate monitor, and nephelometer at SACOL during a dust storm from 27 March to 29 March 2007. The data mainly reflect the characteristics of dust aerosol during the dust storm when man-made pollution emissions are comparatively weaker in non-heating period than that in heating period. In addition, the wind speed is higher and the atmospheric diffusion condition is better, hence a smaller amount of non-dust aerosol in the dust storm compared with that in a non-dust period.

\section{Instrumentation}

The micropulse lidar (CE370-2) includes a co-axial system with a $20 \mathrm{~cm}$ diameter telescope and a Q-switched frequency doubled Nd: YAG laser operated at $532 \mathrm{~nm}$. The pulse repetition frequency is configured at $4.7 \mathrm{kHz}$. The detector is operated in photon-counting mode with a quantum efficiency approaching 55\% and maximum count rate near to $20 \mathrm{MHz}$. It is capable of obtaining the aerosol vertical profiles from ground up to $30 \mathrm{~km}$ (maximum) height with a range resolution of $15 \mathrm{~m}$. The main characteristics are shown in Table 1.

The profiling microwave radiometer (TP/WVP-3000) is a passive remote sensing instrument. It has two profiling systems for temperature and relative humidity, and uses the atmospheric radiation in the frequency band of $22-60 \mathrm{GHz}$, of which $22-30 \mathrm{GHz}$ is for water vapour profile and $51-59 \mathrm{GHz}$ for temperature profile. It can obtain the vertical profiles of temperature, water vapour, and liquid water from ground to $10 \mathrm{~km}$ height with a time resolution of $1 \mathrm{~min}$ and range resolutions of $0.1 \mathrm{~km}$ for the height below $1 \mathrm{~km}$ and $0.25 \mathrm{~km}$ for $1-10 \mathrm{~km}$.

The sunphotometer (CE-318) measures the direct and scattering solar irradiance in the visible and near infrared wavelengths, respectively $1020,870 \mathrm{p} 1,670,440,870 \mathrm{p} 2,870$, 936, and $870 \mathrm{p} 3 \mathrm{~nm}$, of which the bandwidth is $10 \mathrm{~nm}$. It determines the atmospheric spectral transmission, scattering properties, and precipitable water. Its optical head has a sun collimator and sky collimator with a field-of-view of $1.2^{\circ}$. The sun tracking is realised by the evaluation of the solar altitude with a four-quadrant detector. It is now widely used in atmospheric sciences to determine aerosol properties like AOD, Ångström exponent, and precipitable water, which can be applied to the validation of satellite remote sensing.

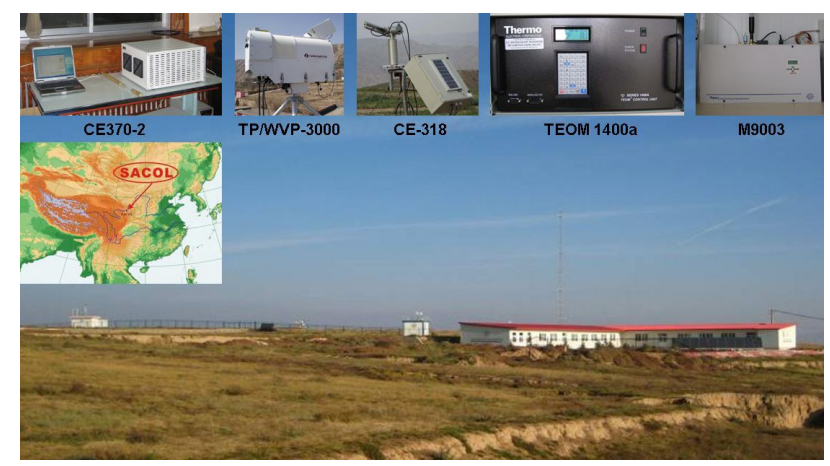

Fig. 1. Location of the Semi-Arid Climate and Environment Observatory of Lanzhou University (SACOL) and relevant instruments.

The particulate monitor (TEOM 1400a) measures $\mathrm{PM}_{10}$ concentration in real-time and long-term. It uses a static balance to monitor the frequency change, which can be inversed to mass concentration. The nephelometer (M9003) observes the aerosol light scattering coefficient at three wavelengths of 450,520 , and $700 \mathrm{~nm}$. The relative humidity of sample air is restricted below $60 \%$ to eliminate its impact on scattering. Background and span calibrations are performed periodically to ensure the data quality.

The specifications of relevant instruments (see Fig. 1) are illustrated in Table 1.

\section{Lidar retrieval method}

An inversion algorithm is modified on the basis of the retrieval method of Klett $(1981,1985)$ and Fernald (1984) to distinguish the aerosol extinction coefficient from that of the atmospheric molecules. The lidar equation for aerosol scattering and molecular scattering is:

$P(z)=E \cdot C \cdot z^{-2}\left[\beta_{1}(z)+\beta_{2}(z)\right] \cdot T_{1}^{2}(z) \cdot T_{2}^{2}(z)$

where $z$ is the range, $P(z)$ the lidar return signal scattered by aerosol and atmospheric molecules, $E$ the output laser pulse energy, $C$ the calibration constant, $\beta(z)$ the backscattering coefficient, $T(z)=\exp \left[-\int_{0}^{z} \sigma(z) d z\right]$ the transmittance, and $\sigma(z)$ the extinction coefficient. The subscript 1 stands for the aerosol while 2 stands for the atmospheric molecules. $\sigma_{2}$ can be obtained using the Rayleigh scattering theory. Then the solution of Eq. (1) for the aerosol backscattering is as follows:

$$
\begin{aligned}
\beta_{1}(z) & =\frac{P(z) z^{2} \exp \left[-2\left(S_{1}-S_{2}\right) \int_{0}^{z} \beta_{2}(z) d z\right]}{\mathrm{CE}-2 S_{1} \int_{0}^{z} P(z) z^{2} \exp \left[-2\left(S_{1}-S_{2}\right) \int_{0}^{z} \beta_{2}\left(z^{\prime}\right) d z^{\prime}\right] d z} \\
& -\beta_{2}(z)
\end{aligned}
$$

If prior information on the aerosol extinction coefficient is available at the reference height $z_{c}$, then the aerosol extinction coefficient at $z$ below $z_{c}$ can be obtained from Eq. (3) (backward solution): 
Table 1. Instrument specifications.

\begin{tabular}{|c|c|c|}
\hline Instrument & Speci & cation \\
\hline CE370-2 & $\begin{array}{l}\text { Transmitter: Actively Q-switched } \\
\text { frequency-doubled Nd: YAG laser } \\
\text { Laser power: } 50 \mathrm{~mW} \\
\text { Pulse width: }<15 \mathrm{~ns} \\
\text { Filter bandwidth: } 0.2 \mathrm{~nm} \\
\text { Telescope field-of-view: } 110 \mu \mathrm{rad} \\
\text { Detection mode: Photon counting } \\
\text { Vertical resolution: } 15 \mathrm{~m}\end{array}$ & $\begin{array}{l}\text { Wavelength: } 532 \mathrm{~nm} \\
\text { Output laser energy: } 8-12 \mu \mathrm{J} \\
\text { Pulse repetition frequency: } 4.7 \mathrm{kHz} \\
\text { Total beam divergence: } 55 \mu \mathrm{rad} \\
\text { Detector: Avalanche photodiode } \\
\text { Acquisition time: }>0.8 \mathrm{~s} \\
\text { Maximum range: } 30 \mathrm{~km}\end{array}$ \\
\hline TP/WVP-3000 & $\begin{array}{l}\text { Calibrated brightness temperature accu- } \\
\text { racy: } 0.5 \mathrm{~K} \\
\text { Water vapour band: } 22-30 \mathrm{GHz} \\
\text { Brightness temperature algorithm for } \\
\text { level } 1 \text { products: Dual gain, } 4 \text { point } \\
\text { nonlinear model }\end{array}$ & $\begin{array}{l}\text { Long term stability: }<1.0 \mathrm{~K} / \mathrm{yr} \\
\text { Oxygen band: } 51-59 \mathrm{GHz} \\
\text { Retrieval algorithms for level } 2 \text { prod- } \\
\text { ucts: Neural networks }\end{array}$ \\
\hline CE-318 & $\begin{array}{l}\text { Wavelengths: } \\
\text { 1020, 870p1, 670,440,870p } 2,870 \text {, } \\
\text { 936, and 870p3 nm } \\
\text { Field-of-view of collimator: } 1.2^{\circ}\end{array}$ & Bandwidth: $10 \mathrm{~nm}$ \\
\hline M9003 & $\begin{array}{l}\text { Principle: } \\
\text { Integrating nephelometer } \\
\text { Scattering angle: } 10^{\circ}-170^{\circ}\end{array}$ & $\begin{array}{l}\text { Wavelengths: } \\
\text { 450, 520, and } 700 \mathrm{~nm} \\
\text { Time resolution: } 5 \mathrm{~min}\end{array}$ \\
\hline
\end{tabular}

$$
\begin{aligned}
& \sigma_{1}(z)=-\frac{S_{1}}{S_{2}} \cdot \sigma_{2}(z)+ \\
& \frac{X(z) \cdot \exp \left[2\left(\frac{S_{1}}{S_{2}}-1\right) \int_{z}^{z_{c}} \sigma_{2}\left(z^{\prime}\right) d z^{\prime}\right]}{\frac{X\left(z_{c}\right)}{\sigma_{1}\left(z_{c}\right)+\frac{S_{1}}{S_{2}} \sigma_{2}\left(z_{c}\right)}+2 \int_{z}^{z_{c}} X\left(z^{\prime}\right) \exp \left[2\left(\frac{S_{1}}{S_{2}}-1\right) \int_{z}^{z_{c}} \sigma_{2}\left(z^{\prime \prime}\right) d z^{\prime \prime}\right] d z^{\prime}}
\end{aligned}
$$

As for the aerosol extinction coefficient at $z$ above $z_{c}$, it can be derived from Eq. (4) (forward solution):

$$
\begin{aligned}
& \sigma_{1}(z)=-\frac{S_{1}}{S_{2}} \cdot \sigma_{2}(z)+ \\
& \frac{X(z) \cdot \exp \left[-2\left(\frac{S_{1}}{S_{2}}-1\right) \int_{z_{c}}^{z} \sigma_{2}\left(z^{\prime}\right) d z^{\prime}\right]}{\frac{X\left(z_{c}\right)}{\sigma_{1}\left(z_{c}\right)+\frac{S_{1}}{S_{2}} \sigma_{2}\left(z_{c}\right)}-2 \int_{z_{c}}^{z} X\left(z^{\prime}\right) \exp \left[-2\left(\frac{S_{1}}{S_{2}}-1\right) \int_{z_{c}}^{z} \sigma_{2}\left(z^{\prime \prime}\right) d z^{\prime \prime}\right] d z^{\prime}}
\end{aligned}
$$

where $X(z)=P(z) z^{2}$ indicates the range normalized lidar return signal, and $S_{1}$ the aerosol extinction-to-backscatter ratio, or lidar ratio (LR), while $S_{2}$, the corresponding extinction-to-backscatter ratio for the atmospheric molecules, is set at $8 \pi / 3$.

In the retrieval, LR must be priori assumed, which makes the retrieved aerosol extinction and backscattering coefficient more relative than absolute (Larchevêque et al., 2002). Generally LR is determined by the aerosol size distribution, shape, and composition (He et al., 2006). LR varies temporally and spatially due to the inhomogeneous distribution of aerosol and cloud (Ansmann et al., 1992). Kovalev (1995) shows that an inappropriately assumed LR will drastically corrupt the retrieval under the inhomogeneous aerosol conditions. Some researches have been made in recent years with lidar measurements and numerical simulations to retrieve LR in different sites (see Table 2). On a basis of a comparison of AOD obtained by lidar and sunphotometer, the study selects the appropriate LR of 20 for the altitude below $2 \mathrm{~km}$ and 25 for that above $2 \mathrm{~km}$ in the lidar data retrieval.

The determination of the reference height is another important assumption. It can be taken in the region where the lidar return signal followed the molecular profile (Marenco et al., 1997). Klett (1981) shows that the backward solution is generally stable. Therefore, in this retrieval, the backward solution is selected.

\section{Results}

The dust storm arrived in Lanzhou at 20:00 (Beijing Time, $1 \mathrm{~h}$ and $3 \mathrm{~min}$ earlier than Lanzhou local time), 27 March and ended at 16:00, 29 March 2007. Figure 2 presents a large scale weather condition during this dust storm using the NCEP/NCAR reanalysis $2.5^{\circ} \times 2.5^{\circ}$ data, and it shows 
Table 2. Lidar ratio from observations and numerical simulation.

\begin{tabular}{|c|c|c|c|}
\hline Authors & Aerosol type & Location and period & $\mathrm{LR}, \operatorname{sr}(532 \mathrm{~nm})$ \\
\hline Ackermann, 1998 & $\begin{array}{l}\text { Continental aerosol } \\
\text { Maritime aerosol } \\
\text { Dust aerosol }\end{array}$ & Numerical simulation & $\begin{array}{l}40-80 \\
15-30 \\
17-25\end{array}$ \\
\hline Liu et al., 2002b & Asian dust aerosol & Japan, 1998-1999 & $42-55$ \\
\hline Immler and Schrems, 2003 & Saharan dust aerosol & $\begin{array}{l}\text { Atlantic Ocean } \\
\text { June } 2000\end{array}$ & 45 \\
\hline Balis et al., 2004 & Dust aerosol & $\begin{array}{l}\text { Thessaloniki, Greece } \\
\text { 2001-2002 }\end{array}$ & $20-100$ \\
\hline He et al., 2006 & Oceanic aerosol & $\begin{array}{l}\text { Hong Kong, China } \\
\text { 2003-2004 }\end{array}$ & $18-44$ \\
\hline Xia, 2006; Han, 2007 & Pollution, dust aerosol & $\begin{array}{l}\text { Lanzhou, China } \\
\text { 2005-2007 }\end{array}$ & $20-25$ \\
\hline \multirow[t]{2}{*}{ Chiang et al., 2008} & Background aerosol & $\begin{array}{l}\text { Taiwan, China } \\
\text { 2002-2004 }\end{array}$ & $47 \pm 15$ \\
\hline & Dust aerosol & & $44 \pm 19$ \\
\hline \multirow[t]{2}{*}{ Xie et al., 2008} & Moderate pollution & $\begin{array}{l}\text { Beijing, China } \\
\text { December } 2007\end{array}$ & $60.8 \pm 13.5$ \\
\hline & $\begin{array}{l}\text { Heavy pollution } \\
\text { Asian dust aerosol }\end{array}$ & & $\begin{array}{l}43.7 \pm 8.3 \\
38.3 \pm 9.8\end{array}$ \\
\hline
\end{tabular}

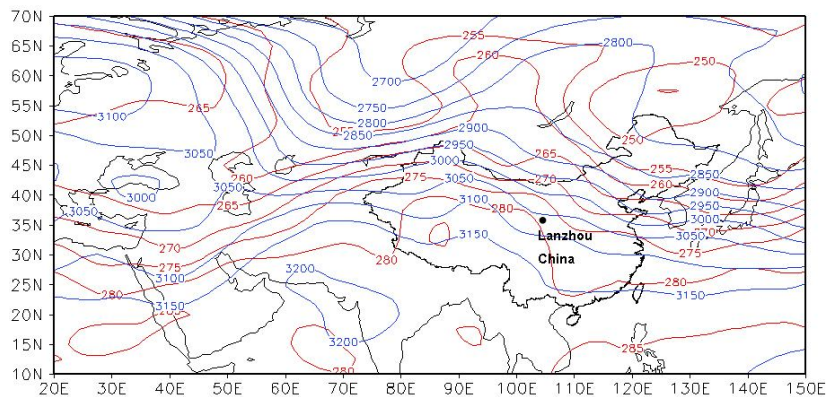

Fig. 2. Distributions of $700 \mathrm{hPa}$ geopotential height and potential temperature at 14:00 (Beijing Time), 28 March 2007. A cold low trough appeared over the west Siberia to the Aral Sea and the Caspian Sea. China was located in front of the cold low trough and the SACOL in the northwest current during the dust storm.

the distributions of $700 \mathrm{hPa}$ geopotential height and potential temperature at 14:00, 28 March. There existed a cold low trough over the west Siberia to the Aral Sea and the Caspian Sea, which would affect the weather condition of East Asia on its east movement. China was located in front of the cold low trough and the SACOL in the northwest current during the dust storm. Figure 3 shows the wind direction and speed

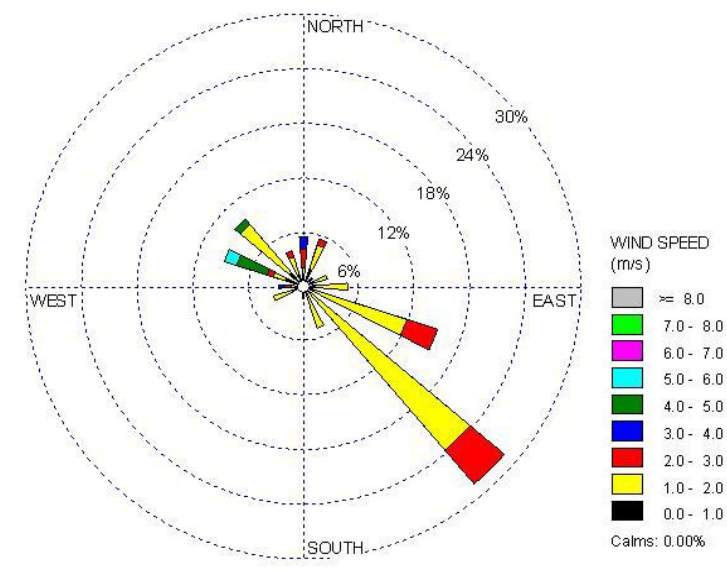

Fig. 3. Wind rose during the dust storm. Wind was observed by a three-axis sonic anemometer CSAT3 $3 \mathrm{~m}$ above the ground at SAOCL from 00:00 (Beijing Time), 27 March to 23:30, 29 March 2007. Southeast wind was dominant and the speed mainly ranged from 1.0 to $3.0 \mathrm{~m} / \mathrm{s}$.

from 00:00, 27 March to 23:30, 29 March, which were observed by a three-axis sonic anemometer CSAT3 set up at SACOL $3 \mathrm{~m}$ above the ground every $30 \mathrm{~min}$. Southeast wind 

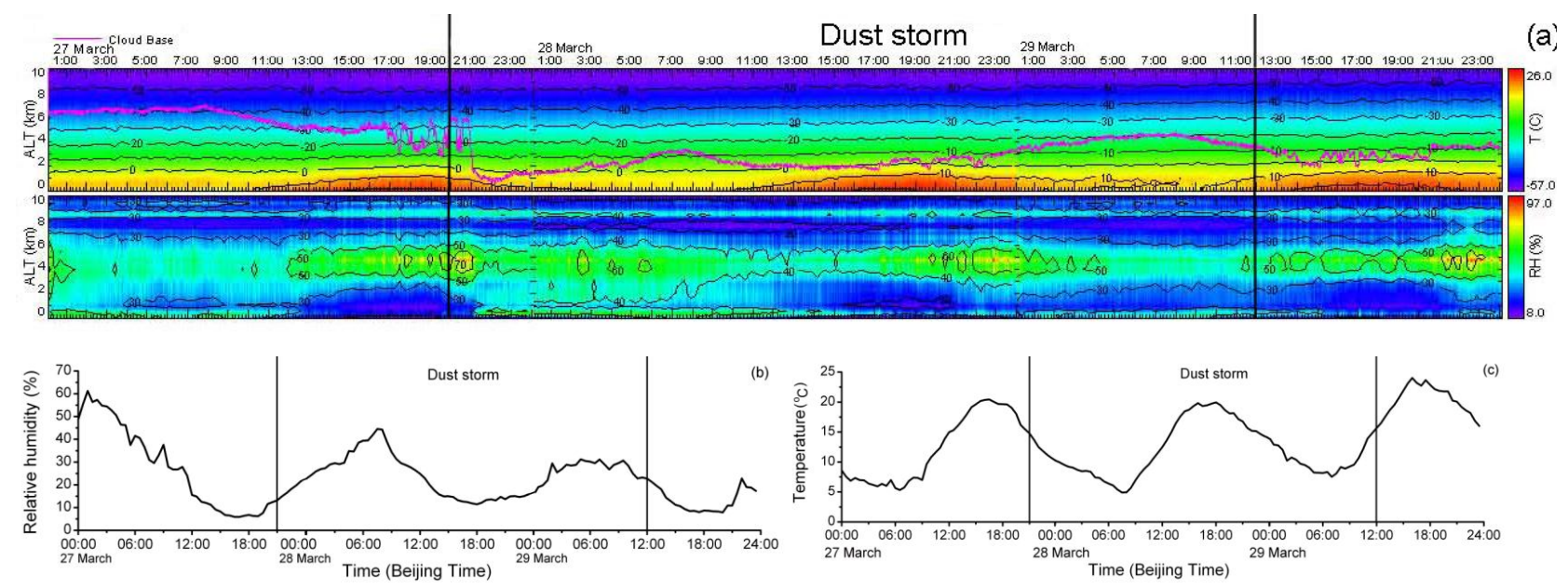

Fig. 4. Temporal evolutions of (a) relative humidity and temperature vertical section, (b) surface relative humidity, and (c) surface temperature.

was dominant over SACOL, the speed ranged from 1.0 to $3.0 \mathrm{~m} / \mathrm{s}$ and the maximum was about $10.0 \mathrm{~m} / \mathrm{s}$. The relative humidity and temperature were shown in Fig. 4, of which the surface relative humidity and temperature were measured by Vaisala HMP45C-L/7, while the vertical profiles of relative humidity and temperature observed by profiling microwave radiometer TP/WVP-3000. During the dust storm, the surface relative humidity presented a diminishing trend from $60 \%$ at 00:00 to $10 \%$ at 20:00, 27 March (see Fig. 4b). The surface temperature was $15.0^{\circ} \mathrm{C}$ at $12: 00,27$ March when no dust storm remained, and it was $12.5^{\circ} \mathrm{C}$ at 12:00, 28 March (see Fig. 4c), which means that dust aerosol probably plays a part in the surface cooling process.

\subsection{Vertical structure of dust aerosol}

Figure 5 presents the temporal evolution of the lidar backscattering signal vertical section from 08:00 (Beijing Time), 27 March to 18:30, 29 March. It can clearly distinguish the aerosol layer from clouds. Before 20:00, 27 March, the aerosol loading was not heavy, and clouds over $5 \mathrm{~km}$ could be observed by lidar. When the dust storm occurred, the lidar detecting height would be reduced, the aerosol was thus mainly concentrated in the low layer, and the lidar backscattering signal became bigger. In this case the dust aerosol was mainly distributed in the layer under $2 \mathrm{~km}$, where the aerosol concentration was relatively high.

Figure 6 presents four different cases for the vertical profiles of dust aerosol extinction coefficient. Firstly the dust aerosol extinction coefficient decreased rapidly with height. The lidar detecting range decreased severely due to the high dust aerosol concentration. The vertical profiles showed that the dust aerosol was concentrated in the layer below $2 \mathrm{~km}$ height, in consistency with the results of Fig. 5. Regarding the dust aerosol extinction coefficient value, the maximum

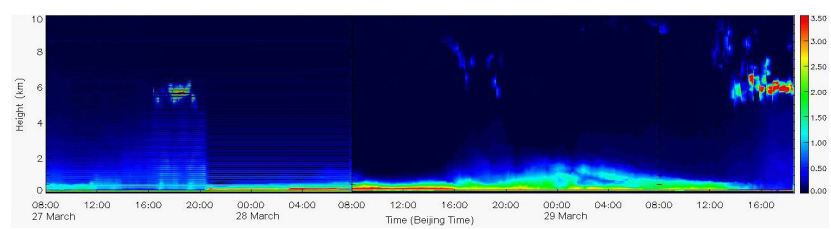

Fig. 5. Temporal evolution of lidar backscattering signal vertical section from 08:00 (Beijing Time), 27 March to 18:30, 29 March 2007. Dust aerosol mainly existed below $2 \mathrm{~km}$.

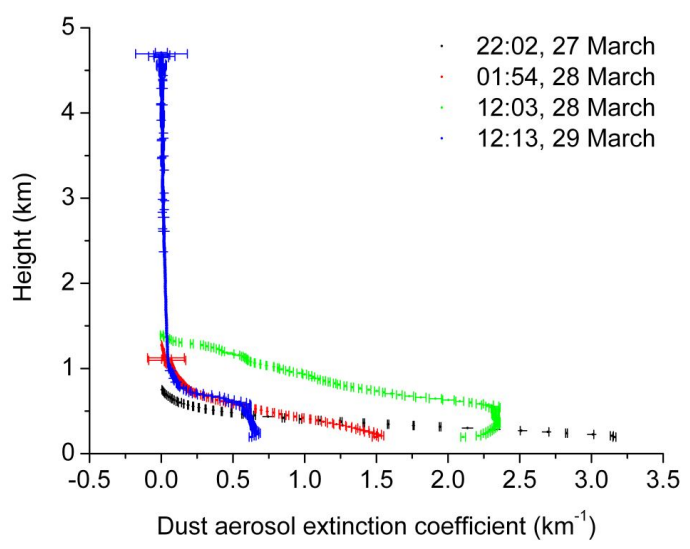

Fig. 6. Vertical profiles of dust aerosol extinction coefficient in four different cases. The dust aerosol extinction coefficient decreased with height.

was $3.16 \mathrm{~km}^{-1}$ at $0.195 \mathrm{~km}$ height. When the dust storm declined at 12:13, 29 March, it decreased to $0.62 \mathrm{~km}^{-1}$ at $0.195 \mathrm{~km}$. 


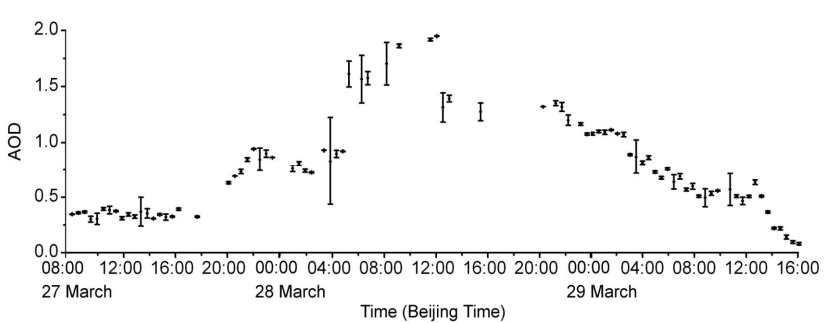

Fig. 7. AOD temporal evolution from 08:00 (Beijing Time), 27 March to 16:00, 29 March 2007. The sub-maximum appeared at 22:00, 27 March and the maximum at 12:00, 28 March.

The paper here discusses the dust aerosol layer below $2 \mathrm{~km}$ height. In comparison with the ground-based network observations made by Murayama et al. (2001) of Asian dust and the vertical distribution analysis of the dust storm in April 1998, the dust height was about $3 \mathrm{~km}$ over Japan, 4 to $5 \mathrm{~km}$ in Seoul and Hefei, and even in the upper troposphere over Japan and Hefei. Thus it is shown that the higher the aerosol height, the further the dust can be sent.

\subsection{AOD temporal evolution}

Figure 7 shows the temporal evolution of AOD retrieved by lidar from 08:00 (Beijing Time), 27 March to 16:00, 29 March. Since the duration between 08:00 and 20:00, 27 March had no dust storm, AOD ranged from 0.3 to 0.4. The result presents the background aerosol properties over Lanzhou and has a good agreement with the result of Huang et al. (2008b). When the dust storm occurred at 20:00, 27 March, the AOD increased with rapidity to 0.63 , which was obviously due to the impact of dust aerosol. Then it reached a sub-maximum of 0.94 at 22:00, 27 March, decreased afterwards to the minimum of 0.72 at 02:20, 28 March, and then increased rapidly again to the maximum of 1.95 at 12:00, 28 March. Then it gradually diminished in the wake of the dust storm. The comparison of Figs. 5 and 7 shows a good consistency.

\subsection{AOD comparison derived by lidar and sunphotometer}

The sunphotometer measures direct solar radiance in voltage shown in Eq. (5):

$$
V_{\lambda}=\left(V_{0 \lambda} / R^{2}\right) \exp \left(-\tau_{\lambda} m\right)
$$

Where $V_{\lambda}$ is the wavelength specific voltage, $V_{0 \lambda}$ the calibration constant, $R$ the Sun-Earth distance, and $m$ the relative optical air mass which is approximated as the secant of the solar zenith angle. $V_{0 \lambda}$ can be derived from the Langley method. If $V_{0 \lambda}$ is already known, the optical depth can be obtained by Eq. (6):

$\tau_{\lambda}=-\ln \left[V_{\lambda} /\left(V_{0 \lambda} / R^{2}\right)\right] / m$

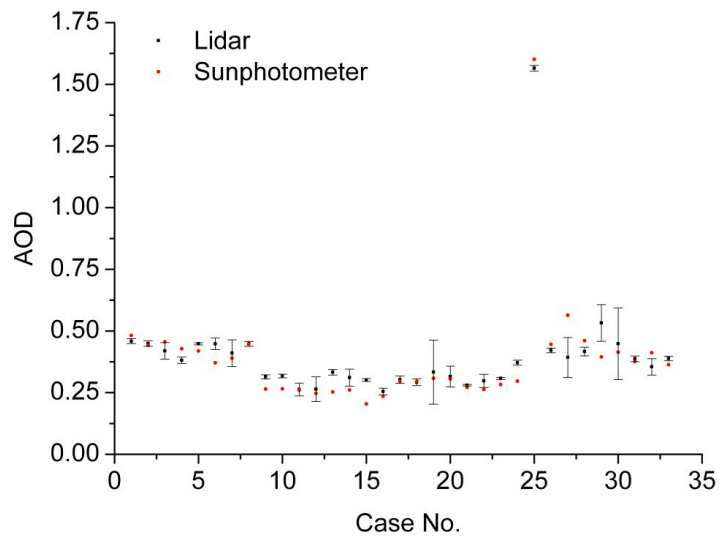

Fig. 8. A comparison of AOD derived by lidar and sunphotometer (Case No. is same as that in Table 3) shows a good consistency between two retrievals.

It is obvious that the accuracy of $\tau_{\lambda}$ depends on the accuracy of $V_{\lambda}$ and $V_{0 \lambda}$. The total optical depth is the results of attenuation by molecules, aerosol, ozone, water vapour, and other uniformly mixed gases, and each of these components can be separated. The atmospheric scattering optical depth can be derived in Rayleigh scattering theory (Hansen and Travis, 1974). The ozone optical depth can be obtained based on tabulated values of ozone absorption coefficient and assumption about ozone amount (Komhyr et al., 1989). The optical depth resulted from other mixed gases can usually be ignored because the impacts of such gases are beyond the band of the sunphotometer. Therefore, AOD can be calculated by Eq. (7):

$\tau_{\alpha \lambda}=\tau_{\lambda}-\tau_{\mathrm{oz} \lambda}-\tau_{r \lambda}$

The level 1.5 cloud-screened AOD data at 870, 675, and $440 \mathrm{~nm}$ from AERONET were used to derive the AOD at $532 \mathrm{~nm}$ using Eq. (8) for a comparison with AOD retrieved by lidar:

$\ln \left(\tau_{\alpha \lambda}\right)=a_{1}+a_{2} \ln (\lambda)+a_{3}[\ln (\lambda)]^{2}$

Figure 8 presents a comparison between the AOD derived by lidar and sunphotometer using the simultaneously collected data of the period before the dust storm and near the end of the dust storm, because the sunphotometer measurement was severely affected by the dust aerosol. The difference between the two retrievals is slight and there exists a good consistency.

In order to further a quantitative comparison between lidar and sunphotometer retrievals, the absolute difference, relative difference, ratio difference, and their mean are calculated. The details are illustrated in Table 3 . The absolute difference is rather small in general, with only two exceptions over 0.13, at 08:50 (Beijing Time) and 10:17, 29 March. The mean absolute difference is 0.041 . The mean relative difference is $12.0 \%$. The mean ratio difference is -0.055 , which 
Table 3. A comparison of AOD derived by lidar and sunphotometer

Absolute Difference $=\left|\mathrm{AOD}_{\text {photometer }}-\mathrm{AOD}_{\text {lidar }}\right|$

Relative Difference $=\left|\mathrm{AOD}_{\text {photometer }}-\mathrm{AOD}_{\text {lidar }}\right| / \mathrm{AOD}_{\text {photometer }}$

Ratio Difference $=2\left(\mathrm{AOD}_{\text {photometer }}-\mathrm{AOD}_{\text {lidar }}\right) /\left(\mathrm{AOD}_{\text {photometer }}+\mathrm{AOD}_{\text {lidar }}\right)$.

\begin{tabular}{|c|c|c|c|c|c|c|}
\hline Case No. & $\begin{array}{r}\text { Date_Time } \\
(\text { ddmm_hhmm })\end{array}$ & $\mathrm{AOD}_{\text {photometer }}$ & $\mathrm{AOD}_{\text {lidar }}$ & $\begin{array}{c}\text { Absolute } \\
\text { Diff. }\end{array}$ & $\begin{array}{l}\text { Relative } \\
\text { Diff.(\%) }\end{array}$ & $\begin{array}{l}\text { Ratio } \\
\text { Diff. }\end{array}$ \\
\hline 1 & 2603_1209 & 0.482 & 0.459 & 0.023 & 4.8 & 0.049 \\
\hline 2 & 2603_1238 & 0.442 & 0.449 & 0.007 & 1.6 & -0.016 \\
\hline 3 & 2603_1307 & 0.456 & 0.419 & 0.037 & 8.1 & 0.085 \\
\hline 4 & 2603_1337 & 0.428 & 0.381 & 0.047 & 11.0 & 0.116 \\
\hline 5 & 2603_1405 & 0.419 & 0.448 & 0.029 & 6.9 & -0.067 \\
\hline 6 & 2603_1434 & 0.370 & 0.448 & 0.078 & 21.1 & -0.191 \\
\hline 7 & 2603_1503 & 0.389 & 0.410 & 0.021 & 5.4 & -0.053 \\
\hline 8 & 2603_1533 & 0.449 & 0.448 & 0.001 & 0.2 & 0.002 \\
\hline 9 & 2703_0830 & 0.264 & 0.314 & 0.050 & 18.9 & -0.173 \\
\hline 10 & 2703_0859 & 0.265 & 0.318 & 0.053 & 20.0 & -0.182 \\
\hline 11 & 2703_0928 & 0.260 & 0.263 & 0.003 & 1.2 & -0.011 \\
\hline 12 & 2703_0957 & 0.247 & 0.264 & 0.017 & 6.9 & -0.067 \\
\hline 13 & 2703_1026 & 0.253 & 0.332 & 0.079 & 31.2 & -0.270 \\
\hline 14 & 2703_1055 & 0.260 & 0.311 & 0.051 & 19.6 & -0.179 \\
\hline 15 & 2703_1124 & 0.204 & 0.301 & 0.097 & 47.5 & -0.384 \\
\hline 16 & 2703_1153 & 0.235 & 0.255 & 0.020 & 8.5 & -0.082 \\
\hline 17 & 2703_1222 & 0.296 & 0.303 & 0.007 & 2.4 & -0.023 \\
\hline 18 & 2703_1251 & 0.296 & 0.292 & 0.004 & 1.4 & 0.014 \\
\hline 19 & 2703_1320 & 0.308 & 0.333 & 0.025 & 8.1 & -0.078 \\
\hline 20 & 2703_1349 & 0.305 & 0.315 & 0.010 & 3.3 & -0.032 \\
\hline 21 & 2703_1418 & 0.271 & 0.280 & 0.009 & 3.3 & -0.033 \\
\hline 22 & 2703_1516 & 0.263 & 0.298 & 0.035 & 13.3 & -0.125 \\
\hline 23 & 2703_1545 & 0.282 & 0.308 & 0.026 & 9.2 & -0.088 \\
\hline 24 & 2703_1614 & 0.296 & 0.371 & 0.075 & 25.3 & -0.225 \\
\hline 25 & 2803_1134 & 1.602 & 1.565 & 0.037 & 2.3 & 0.023 \\
\hline 26 & 2903_0821 & 0.446 & 0.421 & 0.025 & 5.6 & 0.058 \\
\hline 27 & 2903_0850 & 0.564 & 0.393 & 0.171 & 30.3 & 0.357 \\
\hline 28 & 2903_0919 & 0.461 & 0.417 & 0.044 & 9.5 & 0.100 \\
\hline 29 & 2903_1017 & 0.394 & 0.533 & 0.139 & 35.3 & -0.300 \\
\hline 30 & 2903_1046 & 0.414 & 0.448 & 0.034 & 8.2 & -0.079 \\
\hline 31 & 2903_1115 & 0.376 & 0.387 & 0.011 & 2.9 & -0.029 \\
\hline 32 & 2903_1144 & 0.412 & 0.355 & 0.057 & 13.8 & 0.149 \\
\hline \multirow[t]{2}{*}{33} & 2903_1213 & 0.363 & 0.388 & 0.025 & 6.9 & -0.067 \\
\hline & Mean & & & 0.041 & 12.0 & -0.055 \\
\hline
\end{tabular}

means that the AOD derived by lidar is slightly bigger than that by sunphotometer.

\subsection{Temporal evolution of $\mathrm{PM}_{10}$ concentration and scattering coefficient}

Figure 9 gives the temporal evolutions of $\mathrm{PM}_{10}$ concentration and aerosol scattering coefficient every 5 min from 08:00 (Beijing Time), 27 March to 18:30, 29 March. Before 20:00, 27 March there was no dust, the $\mathrm{PM}_{10}$ concentration was mainly below $0.3 \mathrm{mg} / \mathrm{m}^{3}$. Then it increased sharply to the maximum at 22:00, 27 March with a $\mathrm{PM}_{10}$ concentration of $8.836 \mathrm{mg} / \mathrm{m}^{3}$. Afterwards the $\mathrm{PM}_{10}$ concentration decreased with a sub-maximum at 12:00, 28 March, when the $\mathrm{PM}_{10}$ concentration was $3.722 \mathrm{mg} / \mathrm{m}^{3}$. The background aerosol scattering coefficient was mainly below $0.2 \mathrm{~km}^{-1}$. The maximum aerosol scattering coefficients of 450,520, and $700 \mathrm{~nm}$ were $3.045,2.441$, and $1.233 \mathrm{~km}^{-1}$ respectively at 22:00, 27 March, the same as that of $\mathrm{PM}_{10}$ concentration in the maximum. Then it decreased until the end of the dust storm with a sub-maximum at 12:00, $28 \mathrm{March}$, when the scattering coefficients of 450,550 , and $700 \mathrm{~nm}$ were $1.383,1.162$, and $0.537 \mathrm{~km}^{-1}$ respectively. The temporal evolutions of the aerosol scattering coefficients at 450,520 , and $700 \mathrm{~nm}$ and $\mathrm{PM}_{10}$ concentration show similar variation trends. 

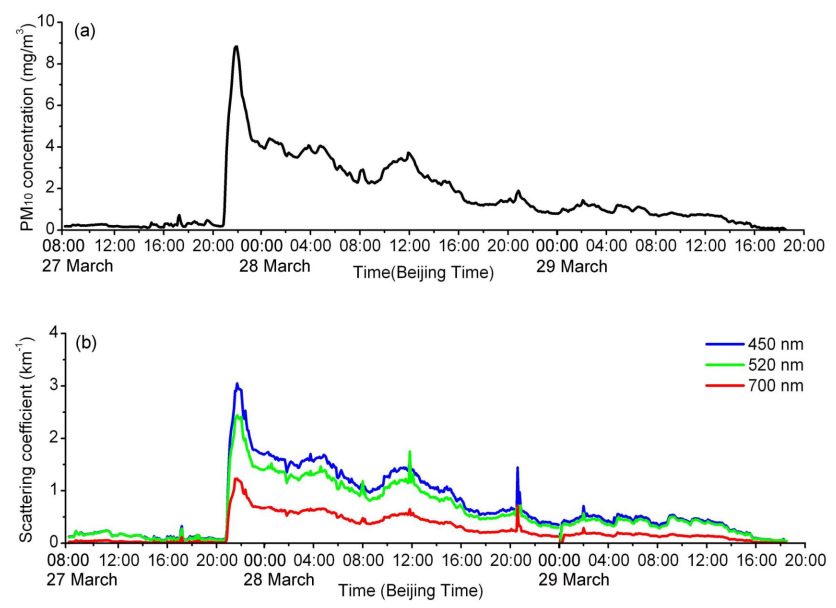

Fig. 9. Temporal evolutions of (a) $\mathrm{PM}_{10}$ concentration and (b) aerosol scattering coefficient from 08:00 (Beijing Time), 27 March to $18: 30,29$ March 2007. The dust aerosol scattering coefficient and $\mathrm{PM}_{10}$ concentration had similar variation trends with the maximums at 22:00, 27 March.

The discrepancy of the peak value of AOD, $\mathrm{PM}_{10}$ concentration, and aerosol scattering coefficient at different time (shown in Figs. 7 and 9) can be discussed in two points. (1) The aerosol vertical distribution was inhomogenous during the dust storm. AOD retrieved from lidar observation reflects integrated extinction properties within lidar detecting range, while $\mathrm{PM}_{10}$ concentration and aerosol scattering coefficient measured on ground surface represents the surface aerosol properties. (2) The aerosol size distribution was changing at different stages of the dust storm. AOD has the scattering effect of the total particulates suspending in the atmosphere, while the $\mathrm{PM}_{10}$ concentration reveals the concentration of the particles with a dynamic diameter of less than $10 \mu \mathrm{m}$.

\subsection{Relationship between aerosol extinction coefficient, relative humidity, and temperature}

Figure 10 presents the profiles of the dust aerosol extinction coefficient (DAEC), relative humidity (RH), and temperature $(T)$ in four different cases. The relative humidity increased slowly with height to the maximum at $0.3 \mathrm{~km}$, then decreased quickly to the minimum at about $1.0 \mathrm{~km}$, and then increased again. The temperature vertical profiles showed a decreasing trend.

As analysed above, the dust aerosol mainly existed in the layer below $2 \mathrm{~km}$, in which the relative humidity had a similar variation trend with the dust aerosol extinction coefficient, and the maximums of the dust aerosol extinction coefficient and relative humidity appeared almost at the same heights. It indicates a correlation between relative humidity and the aerosol extinction coefficient, which can be explained by aerosol hygroscopicity. Many researches on aerosol hygroscopicity have made important progress. Meier
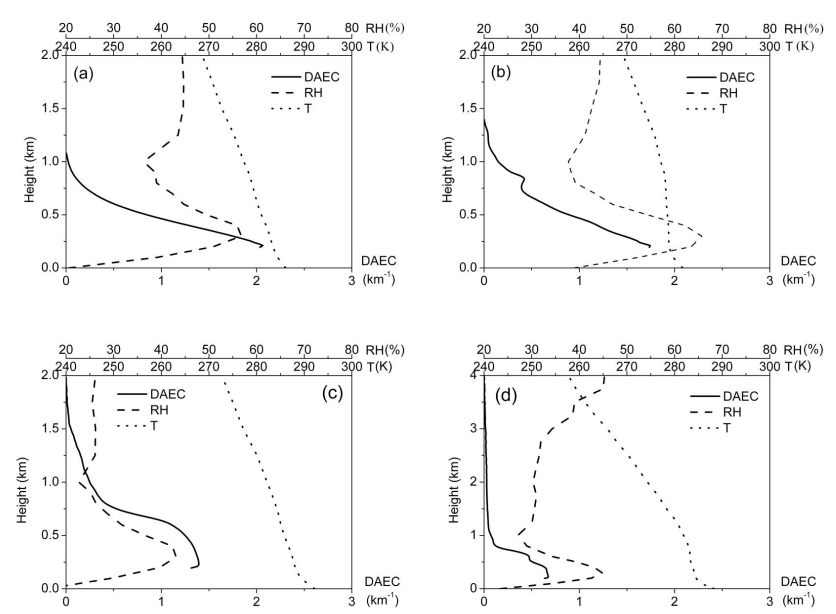

Fig. 10. Vertical profiles of dust aerosol extinction coefficient (DAEC), relative humidity (RH), and temperature ( $T$ ) at (a) 23:00 (Beijing Time), 27 March, (b) 04:48, 28 March, (c) 14:57, 28 March, and (d) 11:15, 29 March 2007. DAEC and RH showed similar variation trends.

et al. (2009) found that the hygroscopic growth factor (HGF) was $1.33 \pm 0.03$ for the clean continental air and $1.40 \pm 0.03$ for the polluted air in Beijing, China. HGF of around 1.0 for one-micrometer dust aerosol and 2.0 for one-micrometer sea salt aerosol were observed during ACE-Asia (Massling et al., 2007). The relative humidity is related with temperature, and then the temperature will affect the aerosol extinction properties by modifying the relative humidity condition.

\subsection{Correlation analysis among $\mathrm{PM}_{10}$ concentration, aerosol extinction, and scattering coefficient}

Figure 11 shows the correlation among $\mathrm{PM}_{10}$ concentration, aerosol extinction coefficient, and scattering coefficient. $\mathrm{PM}_{10}$ concentration and aerosol scattering coefficients of 450,520 , and $700 \mathrm{~nm}$ obviously have a very good linear correlation (see Fig. 11a). All the correlation coefficients between aerosol scattering coefficients at 450, 520, and $700 \mathrm{~nm}$ and $\mathrm{PM}_{10}$ concentration were 0.98 . It presents that the aerosol scattering properties are mainly determined by $\mathrm{PM}_{10}$ concentration.

The aerosol extinction coefficient reflects the total effect of aerosol absorption and scattering. Taking these two elements into consideration, a comprehensive understanding can be made of how the aerosol affects the atmospheric radiation balance and climate change. Figure $11 \mathrm{~b}$ and $\mathrm{c}$ shows the correlation between aerosol extinction coefficient and $\mathrm{PM}_{10}$ concentration, and correlation between aerosol extinction and scattering coefficient. But it should be noted that the aerosol extinction coefficient was retrieved by lidar at the wavelength of $532 \mathrm{~nm}$. Good linear correlations remained and the correlation coefficient between aerosol extinction coefficient and $\mathrm{PM}_{10}$ concentration was 0.94 (see Fig. 11b), 

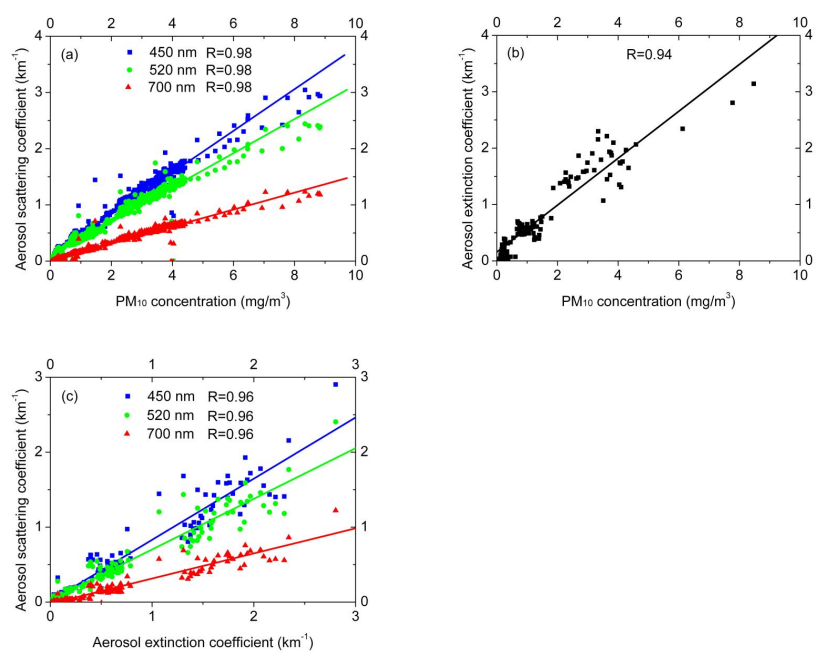

Fig. 11. Correlations of dust aerosol extinction coefficient, scattering coefficient, and $\mathrm{PM}_{10}$ concentration. All the correlation coefficients between aerosol scattering coefficients at 450, 520, and $700 \mathrm{~nm}$ and $\mathrm{PM}_{10}$ concentration were 0.98 (see Fig. 11a). The correlation coefficient of aerosol extinction coefficient retrieved by lidar at the wavelength of $532 \mathrm{~nm}$ and $\mathrm{PM}_{10}$ concentration, of aerosol scattering and extinction coefficient were respectively 0.94 and 0.96 (see Figs. 11b and c).

smaller than that of aerosol scattering coefficient and $\mathrm{PM}_{10}$ concentration due to the unsatisfactory linear correlation of $\mathrm{PM}_{10}$ concentration and absorption coefficient. The correlation coefficients between aerosol scattering coefficients at 450, 520, and $700 \mathrm{~nm}$ and aerosol extinction coefficient at $532 \mathrm{~nm}$ were 0.96 (see Fig. 11c). The slops in Fig. 11c show the ratios of aerosol scattering to extinction at three different wavelengths and also present the aerosol absorption effect.

\section{Summary and discussion}

The dust aerosol radiative properties over Lanzhou are analysed through a case study of the dust storm from 27 March to 29 March 2007 using the data collected by micropulse lidar, profiling microwave radiometer, sunphotometer, particulate monitor, and nephelometer at SACOL.

The dust aerosol is mainly concentrated in the region under $2 \mathrm{~km}$ in height. The dust aerosol extinction coefficient decreases with height. As for the temporal evolution of AOD, its sub-maximum appeared at 22:00 (Beijing Time), 27 March and its maximum at 12:00, 28 March. The comparison between AOD derived by lidar and sunphotometer shows a good consistency. The aerosol scattering coefficient and $\mathrm{PM}_{10}$ concentration present similar trends, with the maximums appearing at 22:00, 27 March.

The aerosol extinction coefficient and relative humidity have the similar trends and their maximums appear almost at the same heights, which shows a correlation between aerosol extinction coefficient and relative humidity known as aerosol hygroscopicity. The temperature may indirectly affect the aerosol extinction properties by modifying the relative humidity condition.

The aerosol extinction coefficient, scattering coefficient, and $\mathrm{PM}_{10}$ concentration present good linear correlations. All the correlation coefficients between the aerosol scattering coefficient of 450, 520, and $700 \mathrm{~nm}$ and $\mathrm{PM}_{10}$ concentration are 0.98 , while that for the correlation between aerosol extinction coefficient retrieved by lidar at the wavelength of $532 \mathrm{~nm}$ and $\mathrm{PM}_{10}$ concentration is 0.94 , and that for the correlation between aerosol extinction coefficient of $532 \mathrm{~nm}$ and scattering coefficient at 450, 520, and $700 \mathrm{~nm}$ are 0.96 .

Nevertheless, due to the data limitation, the paper only presents a dust aerosol case study. Further and more comprehensive observations are still needed in the application of lidar and other instruments to explore the dust aerosol radiative forcing.

Acknowledgements. The research is supported by the National Natural Science Foundation of China (40675078), the National Basic Research Program of China (2006CB400501), and the Arid Meteorology Science Research Foundation of China (IAM200702).

We are also grateful to all the anonymous reviewers for their instructive comments.

Edited by: Q. Fu

\section{References}

Ackerman, A. S., Toon, O. B., Stevens, D. E., Heymsfield, A. J., Ramanathan, V., and Welton, E. J.: Reduction of tropical cloudiness by soot, Science, 288(5468), 1042-1047, 2000.

Ackermann, J.: The extinction-to-backscatter ratio of tropospheric aerosols: a numerical study, J. Atmos. Ocean. Tech., 15, $1043-$ 1050, 1998.

Albrecht, B. A.: Aerosols, cloud microphysics, and fractional cloudiness, Science, 245(4923), 1227-1230, 1989.

Ansmann, A., Riebesell, M., Wandinger, U., Weitkamp, C., Voss, E., Lahmann, W., and Michaelis, W.: Combined Raman elasticbackscatter lidar for vertical profiling of moisture, aerosol extinction, backscatter, and lidar ratio, Appl. Phys. B, 55, 18-28, 1992.

Atwater, M. A.: Planetary albedo changes due to aerosols, Science, 170(3953), 64-66, 1970.

Balis, D. S., Amiridis, V., Nickovic, S., Papayannis, A., and Zerefos, C.: Optical properties of Saharan dust layers as detected by a Raman lidar at Thessaloniki, Greece, Geophys. Res. Lett., 31, L13104, doi:10.1029/2004GL019881, 2004.

Balkanski, Y., Schulz, M., Claquin, T., and Guibert, S.: Reevaluation of Mineral aerosol radiative forcings suggests a better agreement with satellite and AERONET data, Atmos. Chem. Phys., 7, 81-95, doi:10.5194/acp-7-81-2007, 2007.

Blanco, A., Dee Tomasi, F., Filippo, E., Manno, D., Perrone, M. R., Serra, A., Tafuro, A. M., and Tepore, A.: Characterization of African dust over southern Italy, Atmos. Chem. Phys., 3, 2147 2159, doi:10.5194/acp-3-2147-2003, 2003. 
Charlson, R. J. and Pilat, M. J.: Climate: The influence of aerosols, J. Appl. Meteorol., 8(6), 1001-1002, 1969.

Chiang, C. W., Das, S. K., and Nee, J. B.: An iterative calculation to derive extinction-to-backscatter ratio based on lidar measurements, J. Quant. Spectrosc. Ra., 109, 1187-1195, 2008.

Coakley Jr., J. A., Cess, R. D., and Yurevich, F. B.: The effect of tropospheric aerosols on the earth's radiation budget: a parameterization for climate models, J. Atmos. Sci., 40(1), 116-138, 1983.

Collaud Coen, M., Weingartner, E., Schaub, D., Hueglin, C., Corrigan, C., Henning, S., Schwikowski, M., and Baltensperger, U.: Saharan dust events at the Jungfraujoch: detection by wavelength dependence of the single scattering albedo and first climatology analysis, Atmos. Chem. Phys., 4, 2465-2480, doi:10.5194/acp4-2465-2004, 2004.

Fernald, F. G.: Analysis of atmospheric lidar observations: some comments, Appl. Optics, 23(5), 652-653, 1984.

Gobbi, G. P., Barnaba, F., Van Dingenen, R., Putaud, J. P., Mircea, M., and Facchini, M. C.: Lidar and in situ observations of continental and Saharan aerosol: closure analysis of particles optical and physical properties, Atmos. Chem. Phys., 3, 2161-2172, doi:10.5194/acp-3-2161-2003, 2003.

Grassl, H.: Albedo reduction and radiative heating of clouds by absorbing aerosol particles, Contrib. Atmos. Phys., 48, 199-210, 1975.

Han, X.: Retrieval of Lanzhou urban and suburban aerosol radiative properties using lidar measurement, M. S. thesis, Lanzhou University, China, 51 pp., 2007.

Hansen, J. E. and Travis, L. D.: Light scattering in planetary atmospheres, Space Sci. Rev., 16, 527-610, 1974.

Hansen, J., Sato, M., and Ruedy, R.: Radiative forcing and climate response, J. Geophys. Res., 102(D6), 6831-6864, 1997.

He, Q. S., Li, C. C., Mao, J. T., Lau, A. K. H., and Li, P. R.: A study on the aerosol extinction-to-backscatter ratio with combination of micro-pulse LIDAR and MODIS over Hong Kong, Atmos. Chem. Phys., 6, 3243-3256, doi:10.5194/acp-6-3243-2006, 2006

Hong, G., Yang, P., Weng, F. Z., and Liu, Q. H.: Microwave scattering properties of sand particles: application to the simulation of microwave radiances over sandstorms, J. Quant. Spectrosc. Ra., 109, 684-702, 2008.

Huang, J. P., Zhang, W., Zuo, J. Q., Bi, J. R., Shi, J. S., Wang, X., Chang, Z. L., Huang, Z. W., Yang, S., Zhang, B. D., Wang, G. Y., Feng, G. H., Yuan, J. Y., Zhang, L., Zuo, H. C., Wang, S. G., Fu, C. B., and Chou, J. F.: An overview of the semi-arid climate and environment research observatory over the Loess Plateau, Adv. Atmos. Sci., 25(6), 906-921, 2008a.

Huang, J. P., Huang, Z. W., Bi, J. R., Zhang, W., and Zhang, L.: Micro-pulse lidar measurements of aerosol vertical structure over the Loess Plateau, Atmos. Ocean. Sci. Lett., 1(1), 8-11, 2008b.

Huang, J., Fu, Q., Su, J., Tang, Q., Minnis, P., Hu, Y., Yi, Y., and Zhao, Q.: Taklimakan dust aerosol radiative heating derived from CALIPSO observations using the Fu-Liou radiation model with CERES constraints, Atmos. Chem. Phys., 9, 4011-4021, doi:10.5194/acp-9-4011-2009, 2009.

Immler, F. and Schrems, O.: Vertical profiles, optical and microphysical properties of Saharan dust layers determined by a ship-borne lidar, Atmos. Chem. Phys., 3, 1353-1364, doi:10.5194/acp-3-1353-2003, 2003.
Iwasaka, Y., Shi, G. Y., Shen, Z., Kim, Y. S., Trochkine, D., Matsuki, A., Zhang, D., Shibata, T., Nagatani, M., and Nakata, H.: Nature of atmospheric aerosols over the desert areas in the Asian continent: chemical state and number concentration of particles measured at Dunhuang, China, Water Air Soil Poll., 3, 129-145, 2003.

Klett, J. D.: Stable analytical inversion solution for processing lidar returns, Appl. Optics, 2(2), 211-220, 1981.

Klett, J. D.: Lidar inversion with variable backscatter/extinction ratios, Appl. Optics, 24(11), 1638-1643, 1985.

Komhyr, W. D., Grass, R. D., and Leonard, R. K.: Dobson spectrophotometer 83: A standard for total ozone measurements, J. Geophys. Res., 94(D7), 9847-9861, 1989.

Koren, I., Kaufman, Y. J., Remer, L. A., and Martins, J. V.: Measurement of the effect of Amazon smoke on inhibition of cloud formation, Science, 303(5662), 1342-1345, 2004.

Kovalev, V. A.: Sensitivity of the lidar solution to errors of the aerosol backscatter-to-extinction ratio: Influence of a monotonic change in the aerosol extinction coefficient, Appl. Optics, 34(18), 3457-3462, 1995.

Larchevêque, G., Balin, L., Nessler, R., Quaglia, P., Simeonov, V., Bergh, H. V. D., and Calpini, B.: Development of a mulitwavelength aerosol and water-vapor lidar at the Jungfraujoch Alpine Station (3580 m above sea level) in Switzerland, Appl. Optics, 41(15), 2781-2790, 2002.

Liu, H. Z., Zhang, H. S., Bian, L. G., Chen, J. Y., Zhou, M. Y., Xu, X. D., Li, S. M., and Zhao, Y. J.: Characteristics of micrometeorology in the surface layer in the Tibetan Plateau, Adv. Atmos. Sci., 19(1), 73-88, 2002a.

Liu, Z. Y., Sugimoto, N., and Murayama, T.: Extinction-tobackscatter ratio of Asian dust observed with high-spectralresolution lidar and Raman lidar, Appl. Optics, 41(15), 27602767, 2002b.

Marenco, F., Santacesaria, V., Bais, A. F., Balis, D., Sarra, A D., Papayannis, A., and Zerefos, C.: Optical properties of tropospheric aerosols determined by lidar and spectrophotometric measurements (Photochemical activity and solar ultraviolet radiation campaign), Appl. Optics, 36(27), 6875-6886, 1997.

Massling, A., Leinert, S., Wiedensohler, A., and Covert, D.: Hygroscopic growth of sub-micrometer and one-micrometer aerosol particles measured during ACE-Asia, Atmos. Chem. Phys., 7, 3249-3259, doi:10.5194/acp-7-3249-2007, 2007.

McCormick, R. A. and Ludwig, J. H.: Climate modification by atmospheric aerosols, Science, 156(3780), 1358-1359, 1967.

Meier, J., Wehner, B., Massling, A., Birmili, W., Nowak, A., Gnauk, T., Brüggemann, E., Herrmann, H., Min, H., and Wiedensohler, A.: Hygroscopic growth of urban aerosol particles in Beijing (China) during wintertime: a comparison of three experimental methods, Atmos. Chem. Phys., 9, 6865-6880, doi:10.5194/acp9-6865-2009, 2009.

Murayama, T., Sugimoto, N., Uno, I., Kinoshita, K., Aoki, K., Hagiwara, N., Liu, Z. Y., Matsui, I., Sakai, T., Shibata, T., Arao, K., Sohn, B. J., Won, J. G., Yoon, S. C., Li, T., Zhou, J., Hu, H. L., Abo, M., Iokibe, K., Koga, R., and Iwasaka, Y.: Groundbased network observation of Asian dust events of April 1998 in east Asia, J. Geophys. Res., 106(D16), 18345-18359, 2001.

Papayannis, A., Balis, D., Amiridis, V., Chourdakis, G., Tsaknakis, G., Zerefos, C., Castanho, A. D. A., Nickovic, S., Kazadzis, S., and Grabowski, J.: Measurements of Saharan dust aerosols over 
the Eastern Mediterranean using elastic backscatter-Raman lidar, spectrophotometric and satellite observations in the frame of the EARLINET project, Atmos. Chem. Phys., 5, 2065-2079, doi:10.5194/acp-5-2065-2005, 2005.

Pappalardo, G., Amodeo, A., Amoruso, S., Mona, L., Pandolfi, M., and Cuomo, V.: One year of tropospheric lidar measurements of aerosol extinction and backscatter, Ann. Geophys., 46(2), 401413, 2003.

Pierangelo, C., Chédin, A., Heilliette, S., Jacquinet-Husson, N., and Armante, R.: Dust altitude and infrared optical depth from AIRS, Atmos. Chem. Phys., 4, 1813-1822, doi:10.5194/acp-41813-2004, 2004.

Shen, Z. X., Cao, J. J., Li, X. X., Okuda, T., Wang, Y. Q., and Zhang, $X$. Y.: Mass concentration and mineralogical characteristics of aerosol particles collected at Dunhuang during ACE-Asia, Adv. Atmos. Sci., 23(2), 291-298, 2006.

Su, J., Huang, J. P., Fu, Q., Minnis, P., Ge, J. M., and Bi, J. R.: Estimation of Asian dust aerosol effect on cloud radiation forcing using Fu-Liou radiative model and CERES measurements, Atmos. Chem. Phys., 8, 2763-2771, doi:10.5194/acp-8-2763-2008, 2008.

Twomey, S.: The influence of pollution on the shortwave albedo of clouds, J. Atmos. Sci., 34(7), 1149-1152, 1977.
Wang, S. G., Wang, J. Y., Zhou, Z. J., and Shang, K. Z.: Regional characteristics of three kinds of dust storm events in China, Atmos. Environ., 39, 509-520, 2005.

Xia, J. R.: Lidar measurement of atmospheric aerosol radiative properties over Lanzhou, M. S. thesis, Lanzhou University, China, 50 pp., 2006.

Xie, C., Nishizawa, T., Sugimoto, N., Matsui, I., and Wang, Z.: Characteristics of aerosol optical properties in pollution and Asian dust episodes over Beijing, China, Appl. Optics, 47(27), 4945-4951, 2008.

Yamada, M., Iwasaka, Y., Matsuki, A., Trochkine, D., Kim, Y. S., Zhang, D., Nagatani, T., Shi, G. Y., Nagatani, M., Nakata, H., Shen, Z., Chen, B., and Li, G.: Feature of dust particles in the spring free troposphere over Dunhuang in northwestern China: electron microscopic experiments on individual particles collected with a balloon-born impactor, Water Air Soil Pollut., 5, 231-250, 2005.

Zhang, L., Chen, M., and Li, L.: Dust aerosol radiative effect and influence on urban atmospheric boundary layer, Atmos. Chem. Phys. Discuss., 7, 15565-15580, doi:10.5194/acpd-715565-2007, 2007. 